\title{
Bypass surgery to treat symptomatic fusiform dilation of the internal carotid artery following craniopharyngioma resection: report of 2 cases
}

\author{
Long Wang, MD, ${ }^{1}$ Xiang'en Shi, MD, PhD, ${ }^{1,2}$ Fangjun Liu, MD, PhD, ${ }^{2}$ and Hai Qian, MD, $\mathrm{PhD}{ }^{2}$ \\ 1Department of Neurosurgery, Fu Xing Hospital; and 'Department of Neurosurgery, Center for Cerebrovascular Surgery, \\ SanBo Brain Hospital, Capital Medical University, Beijing, People's Republic of China
}

\begin{abstract}
Fusiform dilation of the internal carotid artery (FDICA) is an infrequent vascular complication following resection of suprasellar lesions in the pediatric population, and its course appears to be benign without apparent clinical symptoms. However, data correlating symptomatic FDICA with bypass surgery are scarce. The authors here report 2 symptomatic cases that were treated using internal maxillary artery bypass more than 5 years after total removal of a craniopharyngioma at an outside institution. Both cases of FDICA were resected to relieve the mass effect and to expose the craniopharyngioma. The postoperative course was uneventful, and radiological imaging revealed graft conduit patency. To the authors' knowledge, this is the first reported use of extracranial to intracranial bypass to treat FDICA following removal of a suprasellar lesion. Their findings suggest that bypass surgery is a useful therapeutic approach for symptomatic cases of FDICA and total removal of recurrent craniopharyngioma. Moreover, the indications for surgical intervention and treatment modalities are discussed in the context of previous relevant cases.
\end{abstract}

https://thejns.org/doi/abs/10.3171/2016.9.FOCUS16252

KEY WORDS fusiform dilation of internal carotid artery; iatrogenic fusiform aneurysm; internal maxillary artery; EC-IC bypass; craniopharyngioma; vascular complication

$\mathrm{C}$ RANIOPHARYNGIOMA is one of the most common intracranial tumors in the pediatric population, arising from cells of Rathke's pouch remnants. Radical excision makes the tumor rarely recurrent and provides satisfactory outcomes. The rate of gross-total removal of craniopharyngiomas has reached $90 \%$, and the mortality rate has declined to less than $4 \%$ as practitioners become increasingly experienced. ${ }^{13}$ Although postoperative complications such as hypothalamic dysfunction, diabetes insipidus, vision deterioration, and blood sodium disturbance are not rare following craniopharyngioma resection, only a small number of case series have reported fusiform dilation of the internal carotid artery (FDICA). ${ }^{1-8,10,14-16} \mathrm{Sev}-$ eral factors postulated to contribute to the occurrence of FDICA involve damage to the adventitia or vasa vasorum of the internal carotid artery (ICA). ${ }^{14,15}$ Sutton et al. ${ }^{15}$ originally described this phenomenon with a long-term followup study of 9 cases. In this report, the authors presented 2 cases of FDICA with apparent clinical symptoms, and internal maxillary artery (IMA) bypass was attempted, followed by both dilation and recurrent tumor resection. ${ }^{14}$ Patients in those 2 cases underwent gross-total removal of the craniopharyngioma at an outside institution more than 5 years earlier. Although several reports of surgical intervention to treat FDICA exist in the literature, , ,5, ,7, ,10,14-16 ours is the first report regarding extracranial to intracranial bypass to treat this complication. Our 2 cases bring the number of treated FDICAs to 9. We have also reviewed the literature on related cases, emphasizing the indications and choice of treatment options for FDICA.

\section{Case Reports}

Case 1

History and Examination

A 15-year-old boy presented to our hospital with a 2-year history of right-sided visual deficits. On examination, his neurological function was intact except for bitemporal hemianopia and right-sided decreased visual acuity (finger counting). He had undergone gross-total resection

ABBREVIATIONS FDICA = fusiform dilation of the internal carotid artery; ICA = internal carotid artery; IMA = internal maxillary artery.

SUBMITTED June 14, 2016. ACCEPTED September 23, 2016.

INCLUDE WHEN CITING DOI: 10.3171/2016.9.FOCUS16252. 

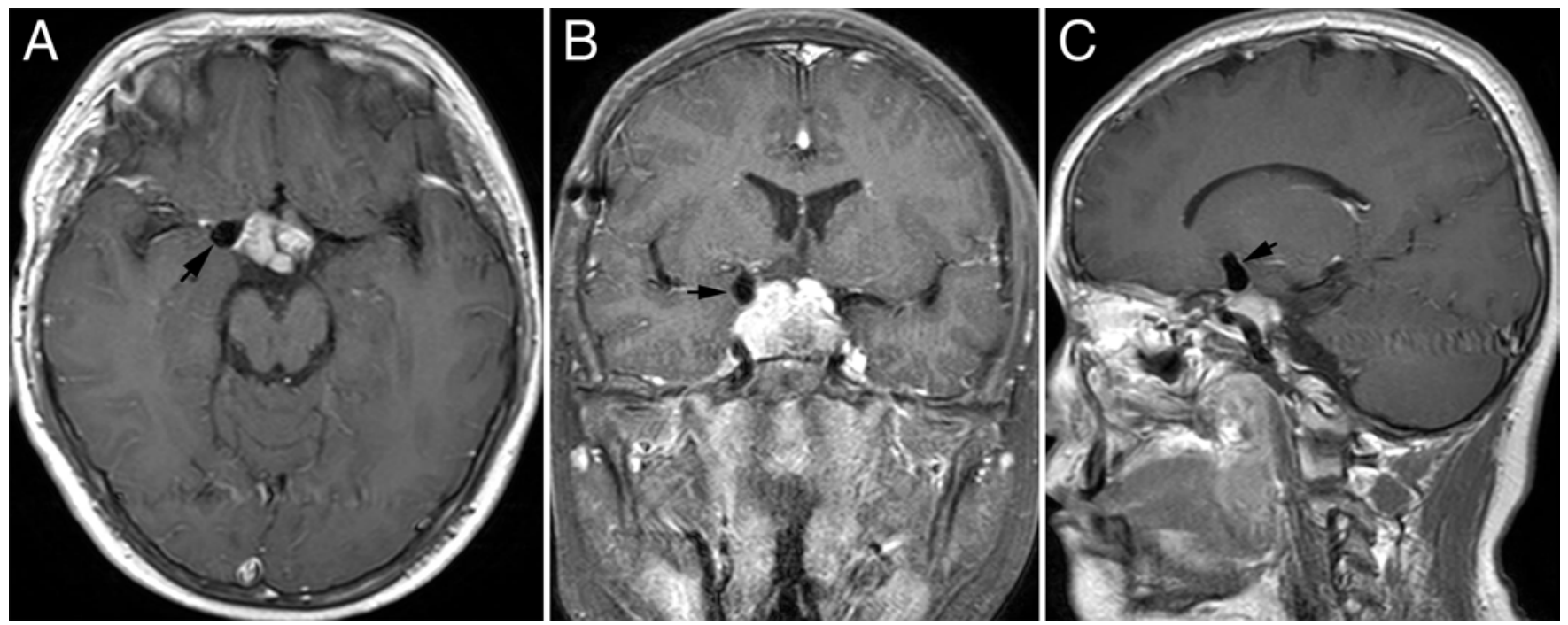

FIG. 1. Case 1. Preoperative axial (A), coronal (B), and sagittal (C) contrast-enhanced MR images showing a 38-mm multicystic lesion that extends into the third ventricle and hypothalamus, compatible with the diagnosis of recurrent craniopharyngioma and fusiform dilation of the right-sided supraclinoid segment of the ICA (arrows).

of a craniopharyngioma via a right pterional approach at a different institution 5.5 years earlier (mid-2010). There were no sequelae after the primary surgery, and he was followed up with contrast-enhanced MRI. Tumor recurrence was detected at the 3-year follow-up (late 2013) but without vascular abnormality. No other attempt at tumor resection or radiotherapy was made. Several months (late 2015) prior to being referred to our hospital, a workup at an outside institution revealed dilation of the right supraclinoid segment of the ICA with a suprasellar lesion consistent with recurrent craniopharyngioma (Fig. 1). This diagnosis was confirmed by cerebral angiography, which excluded other aneurysms or vascular disorders (Fig. 2). His free thyroxin was mildly deficient. Endovascular stent-assisted coiling was attempted unsuccessfully, and the patient was transferred to our hospital for further management.

\section{Operation}

The surgical complications and possible treatment regimens were carefully discussed with the child's parents. A decision was made to treat both lesions in one operation. An IMA bypass, which we have described in previous reports, ${ }^{11,12}$ was performed via an end-to-end anastomosis (IMA to proximal radial artery), followed by an end-toside anastomosis (distal radial artery to $\mathrm{M}_{2}$ segment). Then, the FDICA was clipped after aneurysmorrhaphy to expose the tumor. The recurrent craniopharyngioma was exposed in the suprasellar cistern and was totally removed (Fig. 3).
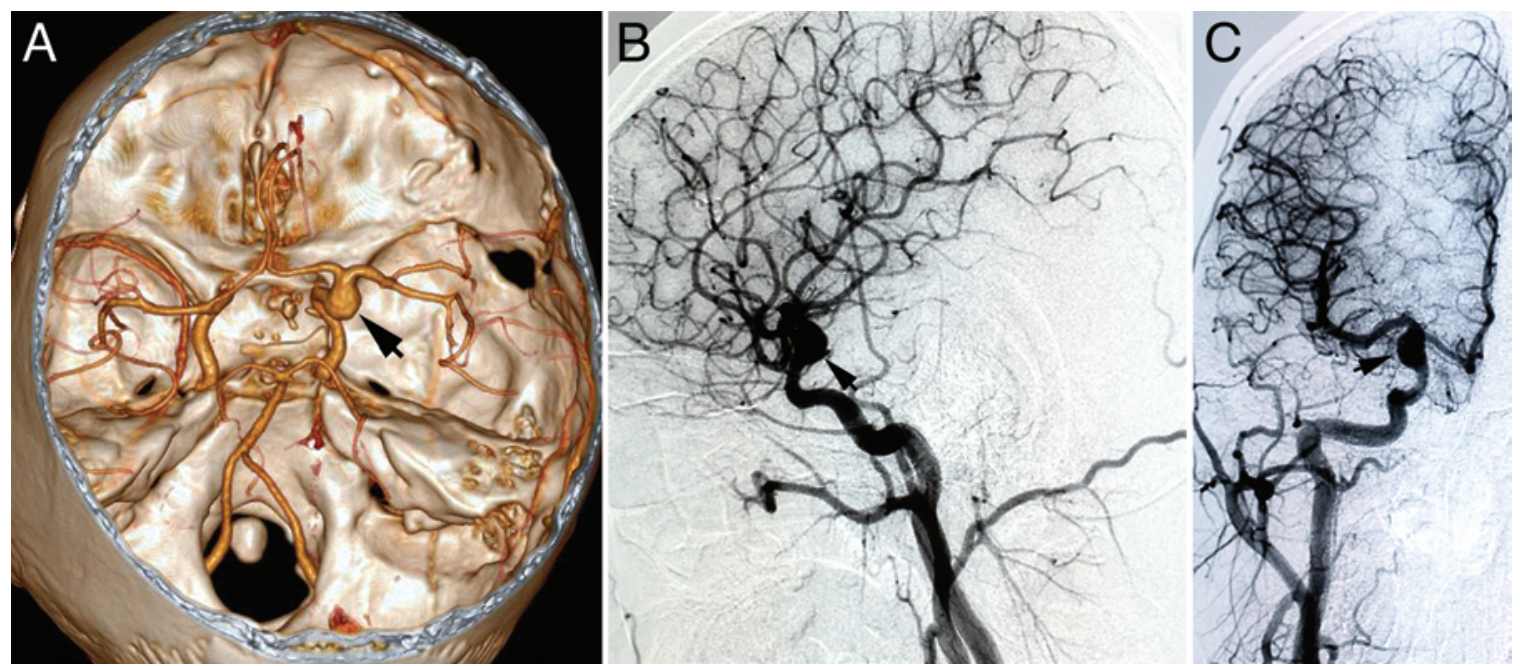

FIG. 2. Case 1. Preoperative fusion 3D CT angiogram (A) and digital subtraction angiograms (B and C) confirmed dilation of the ICA with a maximum diameter of $9 \mathrm{~mm}$ (arrows). The lesion extends from the origin of the posterior communicating artery to the bifurcation of the ICA. 


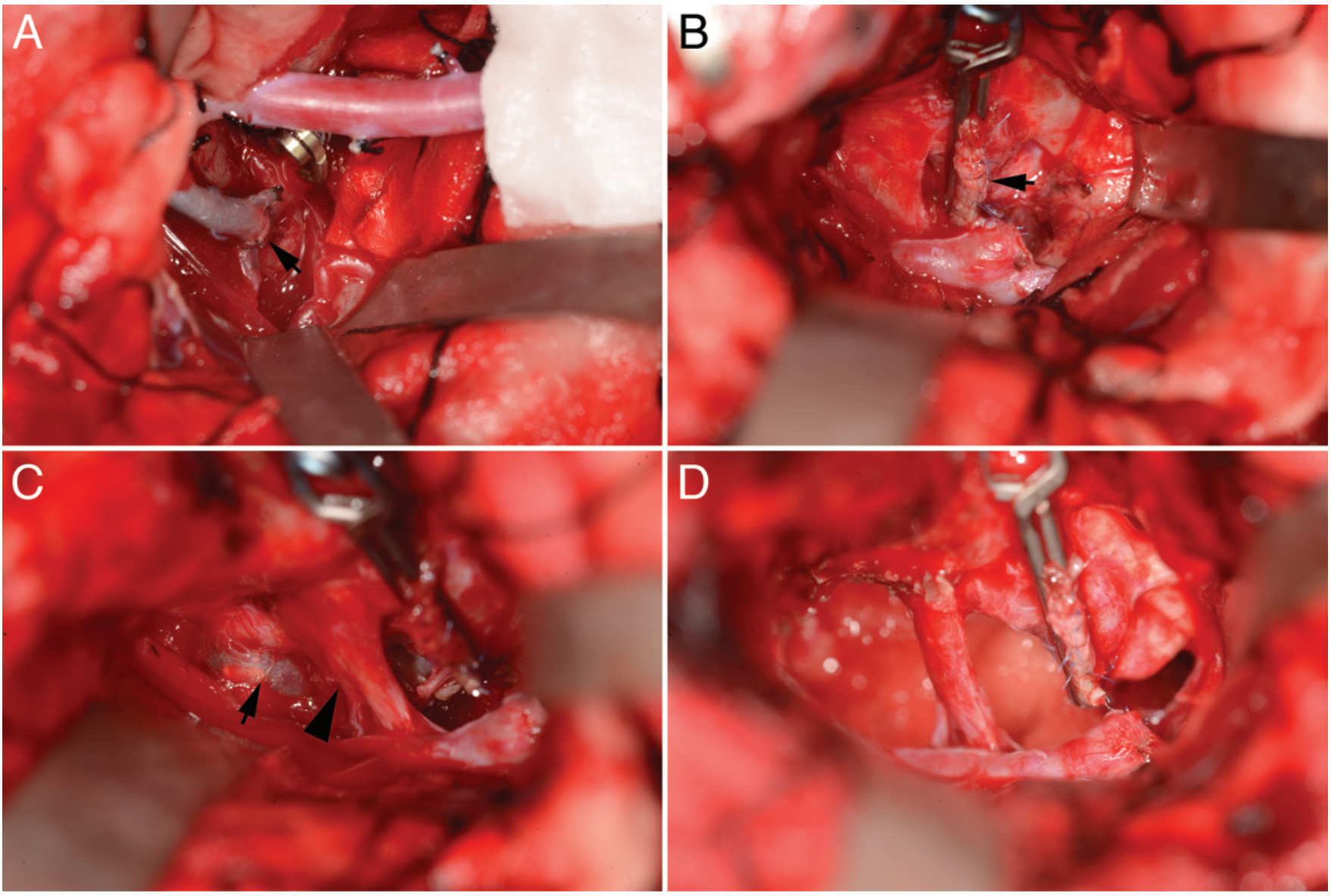

FIG. 3. Case 1. Intraoperative photographs showing the anastomosis site (arrow, $\mathbf{A}$ ) between the radial artery and $\mathrm{M}_{2}$ segment, continuous suture points (arrow, B) following aneurysmorrhaphy and clipping, the recurrent craniopharyngioma (arrow, C) and optic nerve (arrowhead), and the surgical field (D) after resection of the tumor and dilation.

\section{Postoperative Course}

The boy's postoperative course was uneventful. He was treated with hormonal substitution therapy, and no complaints or evidence of neurological deficits occurred. His impaired visual acuity did not progress any further before discharge. Magnetic resonance imaging and cerebral angiography revealed total removal of the craniopharyngioma (Fig. 4), disappearance of the FDICA, and graft artery pa-
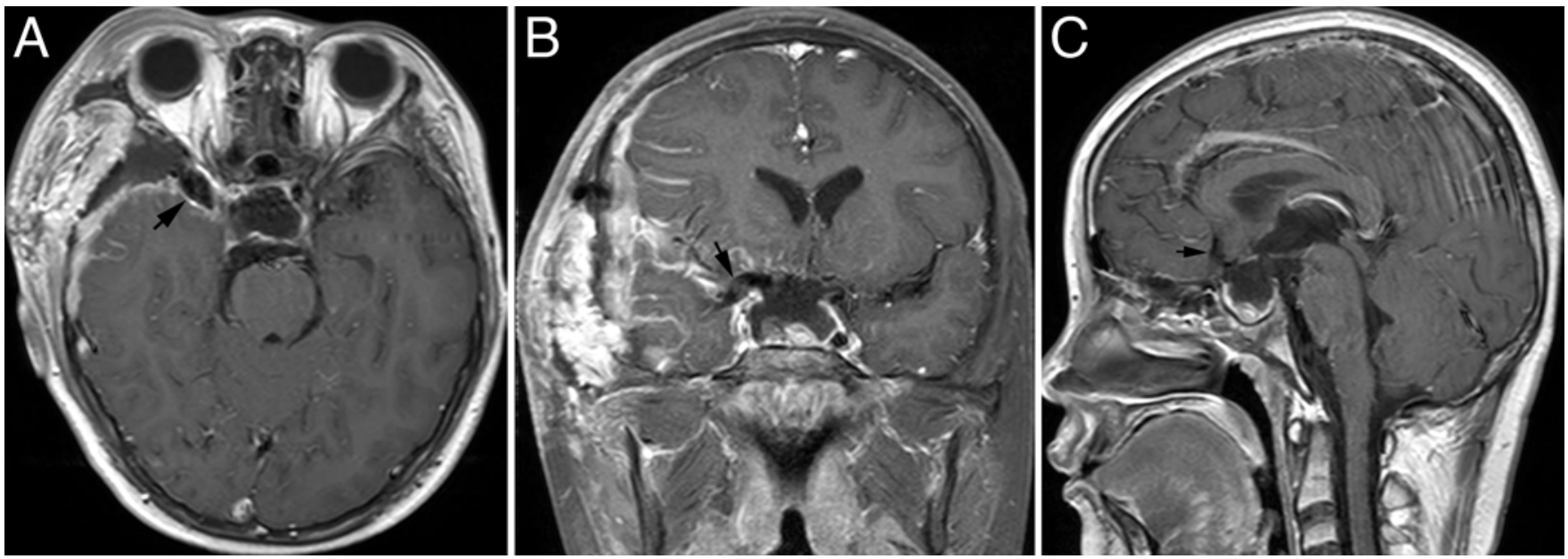

FIG. 4. Case 1. Axial (A), coronal (B), and sagittal (C) views of postoperative contrast-enhanced MRI demonstrating gross-total resection of the tumor. 

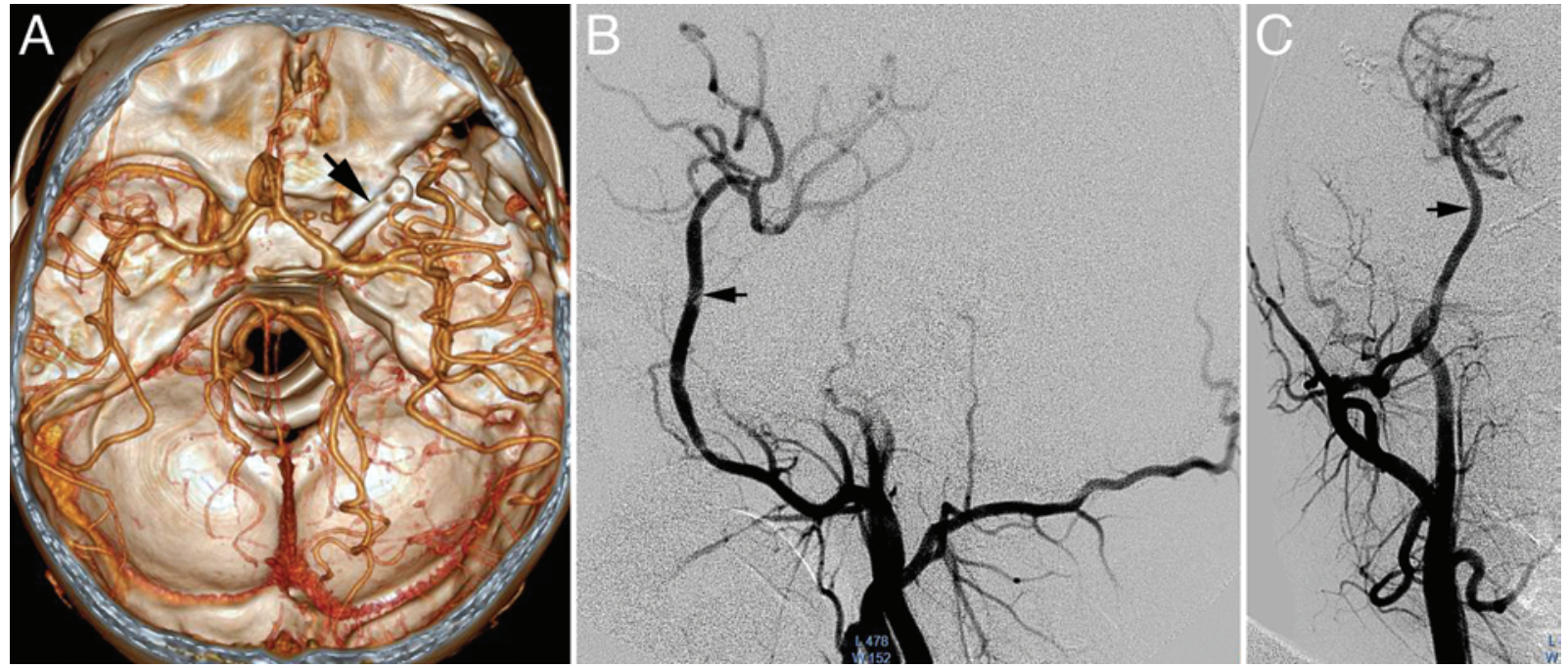

FIG. 5. Case 1. Postoperative 3D CT angiogram (A) revealing elimination of the FDICA by clipping (arrow). Anteroposterior (B) and lateral (C) angiograms showing graft artery patency (arrow).

tency (Fig. 5). The patient was given replacement medication after discharge and has returned to school. Follow-up at 3 months showed intact neurological function without any surgery-related sequelae.

\section{Case 2}

\section{History and Examination}

A 13-year-old girl was referred to our hospital with a 3 -month history of severe headache and vomiting. Her neurological function was intact on admission. More than 5 years (September 2009) before being referred to our department, she had undergone gross-total resection of a craniopharyngioma at a different institution. The tumor was approached via a right frontotemporal craniotomy, and her postoperative course was uneventful without neurological deficits. She was periodically assessed with contrastenhanced MRI after discharge. Two months prior to presenting at our institute (October 2014), her headaches had begun and rapidly progressed. On admission, she complained of severe headache and interrupted vomiting. Her free thyroxin was mildly deficient. Serial imaging studies performed at an outside institution (October 2014) showed a dilated right ICA but no tumor recurrence. The patient had no family history of migraine, and the aggravation of her clinical course was attributed to progression of an FDICA. Preoperative MRI and digital subtraction angiography showed an FDICA extending from the posterior communicating artery to the bifurcation of the ICA (Figs. 6 and 7). She was transferred to our hospital for further management after unsuccessful endovascular treatment.
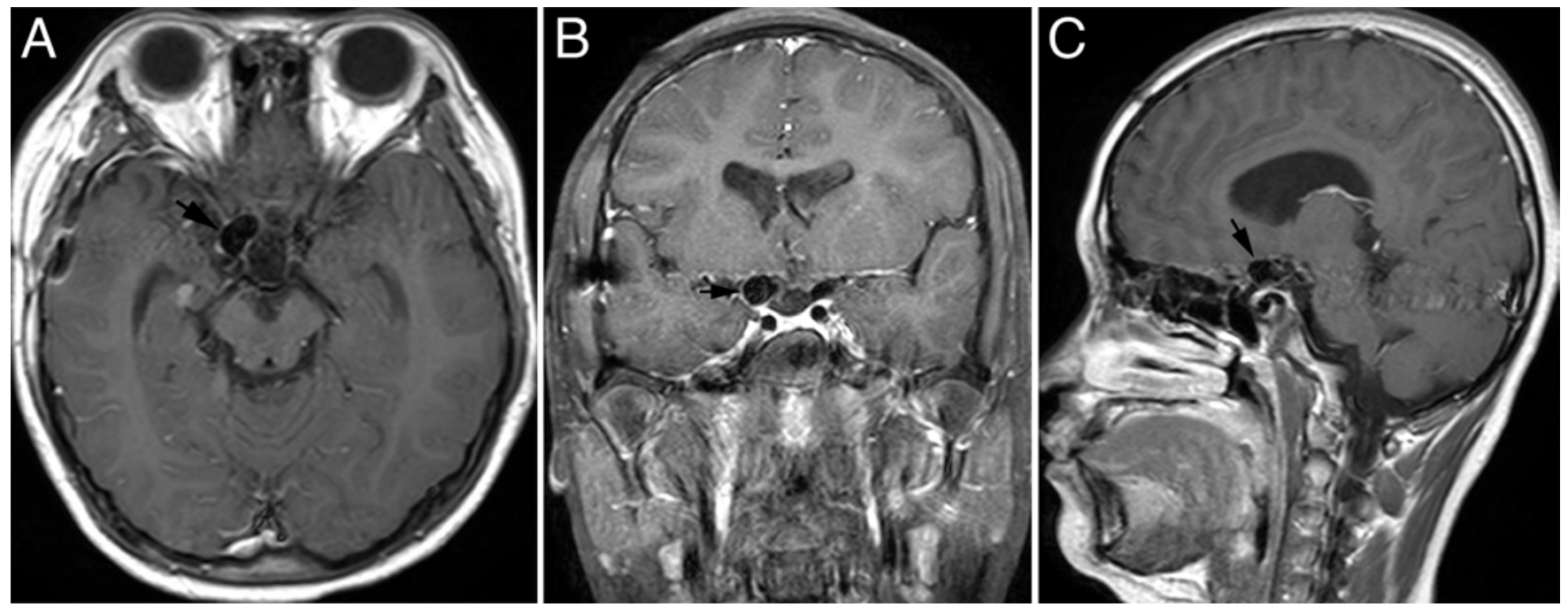

FIG. 6. Case 2. Preoperative axial (A), coronal (B), and sagittal (C) contrast-enhanced MR images showing a flow-void area in the suprasellar region consistent with an FDICA (arrow). A tumor recurrence was not detected on the neuroimaging. 


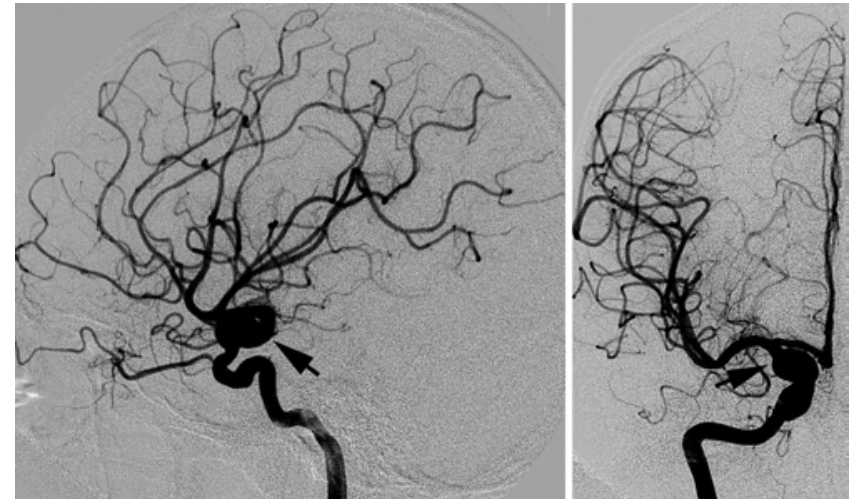

FIG. 7. Case 2. Preoperative lateral (left) and anterioposterior (right) digital subtraction angiograms confirmed dilation of the ICA with a maximum diameter of $21 \mathrm{~mm}$ (arrows). The lesion involves the supraclinoid segment of the ICA.

\section{Operation}

Following careful discussion with the child's parents regarding headache control, risk of hemorrhage, and longterm outcomes, a surgical plan was established to treat the FDICA by cerebral vascularization with or without resection of the FDICA (Fig. 8A and B). However, after opening the suprasellar and interpeduncular cistern, a small residual tumor tightly adhering to surrounding arteries was detected (Fig. 8C). According to our accumulated experience, an end-to-end anastomosis (IMA to proximal radial artery) and then an end-to-side anastomosis (distal radial artery to $\mathrm{M}_{2}$ segment) were performed at the first step. The dilation of the supraclinoid ICA was excised after trapping. After suturing the distal end of the ICA, the craniopharyngioma was radically resected from the adjacent vessels.

\section{Postoperative Course}

The girl's postoperative course was uneventful except for a temporal hematoma that was evacuated on the 1st day after the bypass surgery. The patient remained neurologically intact and her headache resolved. A postoperative angiogram demonstrated a patent graft artery and disappearance of the FDICA (Fig. 9). The patient was given replacement medication including Euthyrox and hydrocortisone and has returned to school. Follow-up at 10 months after surgery showed intact neurological function without any surgery-related sequelae.

\section{Discussion}

Fusiform dilation of the ICA is a rare vascular complication of surgery for craniopharyngioma, especially at centers in which radical tumor excision is the policy. ${ }^{16}$ Since the first report by Sutton and colleagues, ${ }^{15} 37$ cases of FDICA after craniopharyngioma removal have been reported in the literature, excluding our 2 bypass cases. The incidence rate of FDICA ranges from $2.4 \%$ to $29 \%,{ }^{1-3,14,15}$ and all cases have occurred in the pediatric population. The natural history of FDICA seems to be benign in most instances, and none of the reported cases have suffered from hemorrhage or ischemic episodes..$^{1-8,10,14-16}$ This phe-
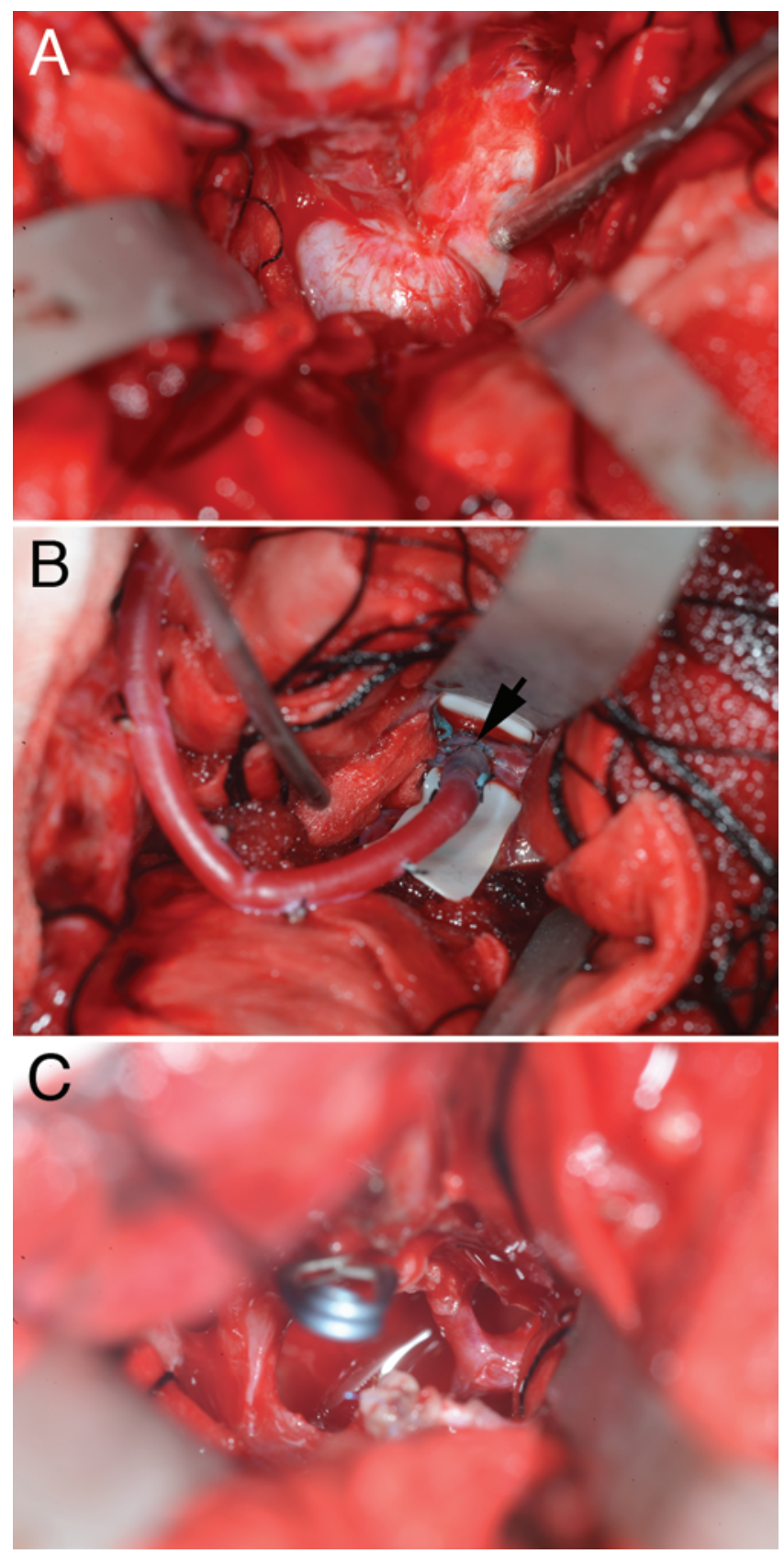

FIG. 8. Case 2. Intraoperative photographs showing exposure of the right FDICA in the suprasellar region (A), the anastomosis site (arrow) between the radial artery and $M_{2}$ segment as well as continuous suture points (arrow, B) following aneurysmorrhaphy and clipping, and the surgical field (C) after resection of the craniopharyngioma with proximal clipping of the supraclinoid segment of the ICA.

nomenon of FDICA tends to occur ipsilateral to the surgical exposure as a result of the intraoperative manipulation of the ICA. ${ }^{10}$ With regard to its pathogenesis, FDICA has been postulated to occur as a result of the self-healing process following injury to the carotid artery. ${ }^{8}$ The "hyperplasia mechanism" suggests that microdamage to the adventitia from surgical manipulation could trigger the natural healing process of the arterial wall in which the adventitia and its vasa vasorum develop. This theory is strongly sup- 

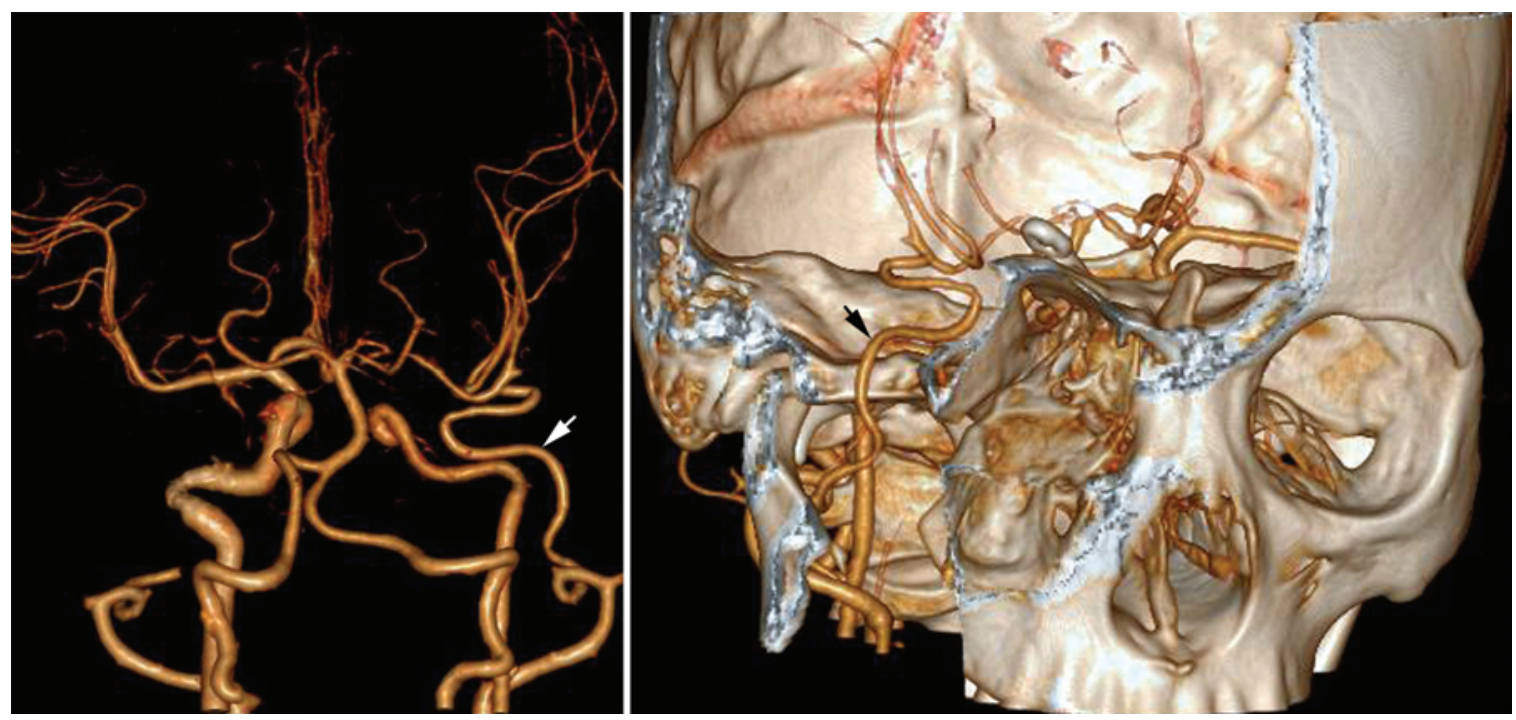

FIG. 9. Case 2. Postoperative 3D CT angiograms revealing a patent radial artery (arrows) and elimination of the FDICA.

ported by histological findings that have shown the neogenesis of the vasa vasorum and an increase of collagen fiber in the adventitia.

The conservative or aggressive management of FDICA after craniopharyngioma resection remains a controversial issue. Most cases have a stable clinical course, and the conservative approach with radiographic observation is recommended in these cases. ${ }^{1-3,6,14,15}$ Surgical exploration should be reserved for symptomatic patients, such as those with persistent or severe headache attributed to the lesion, neurological deficits from mass effect, thromboembolic events, or focal changes in morphological characteristics. ${ }^{2,9}$ Liu et al. ${ }^{7}$ described a case that rapidly evolved in size and argued that FDICA may not be indolent. Since the first reported case, a small cohort of symptomatic FDICA cases has been documented, and these cases were surgically managed, 3 by surgical clipping and 2 by endovascular coiling (Table 1). ${ }^{4,5,8,10,16}$ It should be noted that clipping was performed in a case by Sutton, ${ }^{15}$ not for the purpose of treatment but for tumor exposure. The outcome after surgical intervention seemed to be satisfactory, and all the patients recovered well.

In the current report, 2 patients presented with devastating headache or impaired visual deficit due to the mass effect of FDICA; therefore, surgical manipulation was strongly indicated. According to preoperative angio-

TABLE 1. Literature summary of treated cases of FDICA

\begin{tabular}{|c|c|c|c|c|c|c|c|c|c|c|}
\hline $\begin{array}{l}\text { Case } \\
\text { No. }\end{array}$ & $\begin{array}{l}\text { Authors } \\
\& \text { Year }\end{array}$ & $\begin{array}{c}\text { Age at CP } \\
\text { Resection } \\
\quad(y r s)\end{array}$ & $\begin{array}{l}\text { Surgical } \\
\text { Maneuver } \\
\text { for CP }\end{array}$ & $\begin{array}{c}\text { Tumor } \\
\text { Recurrence }\end{array}$ & $\begin{array}{c}\text { 1st } \\
\text { Visualization } \\
\text { of FDICA }\end{array}$ & $\begin{array}{c}\text { Location } \\
\text { of } \\
\text { FDICA }\end{array}$ & $\begin{array}{c}\text { Age at FDICA } \\
\text { Treatment } \\
\text { (yrs) }\end{array}$ & $\begin{array}{l}\text { Reason } \\
\quad \text { for } \\
\text { Intervention }\end{array}$ & $\begin{array}{l}\text { Surgical } \\
\text { Maneuver }\end{array}$ & $\begin{array}{l}\text { Current } \\
\text { Status }\end{array}$ \\
\hline 1 & $\begin{array}{l}\text { Liu et al., } \\
\quad 1991\end{array}$ & 24 & Rt pterional, GTR & No & 3 mos later & $\begin{array}{l}\text { Rt supra- } \\
\text { clinoid }\end{array}$ & 27 & $\begin{array}{c}\text { Enlarge- } \\
\text { ment }\end{array}$ & Clipping & NA \\
\hline 2 & $\begin{array}{l}\text { Sutton, 1994; } \\
\text { Sutton et } \\
\text { al., } 1994\end{array}$ & 12 & Rt pterional, STR & Yes & 15 mos later & $\begin{array}{l}\text { Rt supra- } \\
\text { clinoid }\end{array}$ & 15 & $\begin{array}{l}\text { Exposure of } \\
\mathrm{CP}\end{array}$ & Clipping & $\begin{array}{l}\text { Died of } \\
\text { recur- } \\
\text { rent CP }\end{array}$ \\
\hline 3 & $\begin{array}{l}\text { Lakhanpal et } \\
\text { al., } 1995\end{array}$ & 14 & NA & NA & NA & $\begin{array}{l}\text { Rt supra- } \\
\text { clinoid }\end{array}$ & NA & $\begin{array}{l}\text { Visual im- } \\
\text { pairment }\end{array}$ & Clipping & NA \\
\hline 4 & $\begin{array}{r}\text { Tirakotai et } \\
\text { al., } 2002\end{array}$ & 10 & $\begin{array}{l}\text { Rt pterional OZ, } \\
\text { GTR }\end{array}$ & No & 12 mos later & $\begin{array}{l}\text { Rt supra- } \\
\text { clinoid }\end{array}$ & 16 & Headache & Clipping & $\begin{array}{l}\text { Well recov- } \\
\text { ered }\end{array}$ \\
\hline 5 & $\begin{array}{l}\text { Nagata et al., } \\
2010\end{array}$ & $4 / 5$ & $\begin{array}{l}\text { Bilat } \mathrm{OZ}+\text { It SO, } \\
\text { STR }\end{array}$ & Yes & 14 mos later & $\begin{array}{l}\text { Bilat } \\
\text { supra- } \\
\text { clinoid }\end{array}$ & 5.17 & $\begin{array}{l}\text { Visual im- } \\
\text { pairment }\end{array}$ & Lt clipping & NA \\
\hline 6 & $\begin{array}{l}\text { Ogilvy et al., } \\
2011\end{array}$ & 4 & $\begin{array}{l}\text { Transcallosal + rt } \\
\text { pterional OZ, GTR }\end{array}$ & No & 3 mos later & $\begin{array}{l}\text { Lt supra- } \\
\text { clinoid }\end{array}$ & 5 & $\begin{array}{c}\text { Enlarge- } \\
\text { ment }\end{array}$ & Coiling & $\begin{array}{l}\text { Well recov- } \\
\text { ered }\end{array}$ \\
\hline 7 & Li et al., 2015 & 7 & Rt pterional, GTR & Yes & 48 mos later & $\begin{array}{l}\text { Rt supra- } \\
\text { clinoid }\end{array}$ & 13 & Headache & Coiling & $\begin{array}{l}\text { Well recov- } \\
\text { ered }\end{array}$ \\
\hline
\end{tabular}

$\mathrm{CP}=$ craniopharyngioma; GTR = gross-total resection; NA = not available; $\mathrm{OZ}$ = orbitozygomatic approach; $\mathrm{SO}$ = suboccipital approach; STR = subtotal resection. 


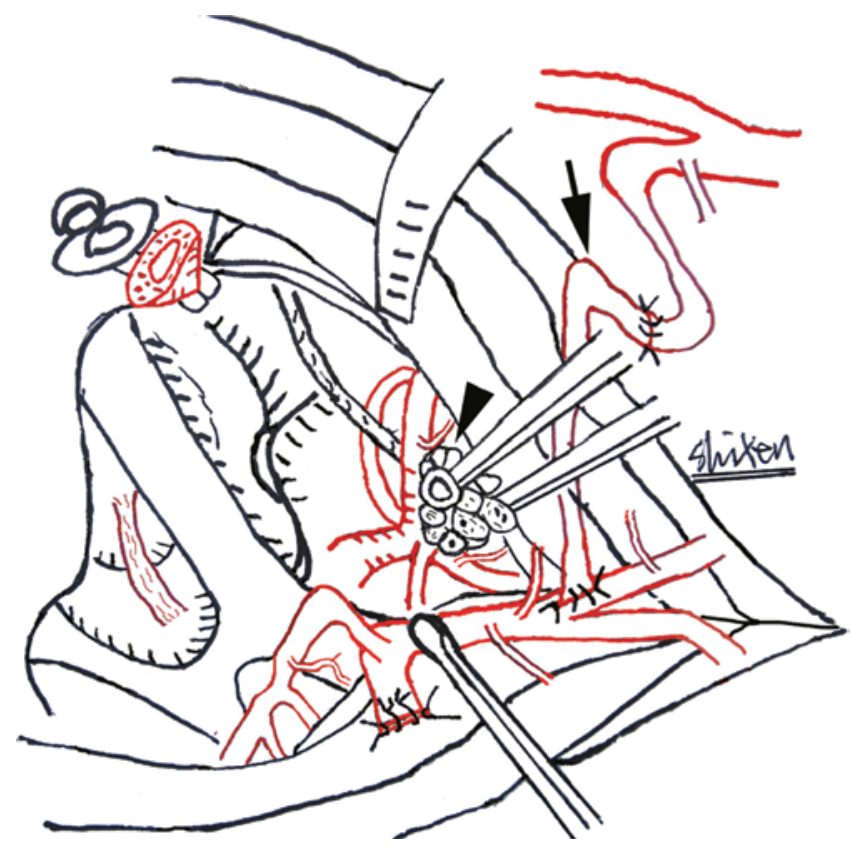

FIG. 10. Drawing of the extended surgical field for the recurrent craniopharyngioma (arrowhead) resection after removal of the FDICA. The radial artery grafting (arrow) was patent following bilateral anastomosis. Copyright Xiang'en Shi. Published with permission.

graphic studies, the FDICA extended from the posterior communicating artery to the bifurcation of the ICA. Thus, the vital perforators arising from the dilation made clip reconstruction or coiling difficult. Given our accumulated experience and expertise in cerebral revascularization, we considered bypass surgery performed by our team to be a safe and effective treatment modality for FDICA. At the same time, recurrent craniopharyngioma was detected preoperatively, so the tumor resection was preferable following the bypass. During the procedure, we found that the vital structures were compressed from mass effect of the FDICA. So resection of the dilation was performed to expand the surgical space for further removal of the recurrent tumor (Fig. 10). These complicated surgeries were successfully performed, and postoperative imaging showed a patent graft conduit and the disappearance of the FDICA and recurrent craniopharyngioma.

From our perspective, surgical intervention for FDICA should be considered in a small subset of patients, especially those whose clinical symptoms have continuously developed or when secondary resection of a recurrent craniopharyngioma is needed. Moreover, we propose that few asymptomatic cases that have continuously progressed for more than 18 months after the original removal of the craniopharyngioma should be treated with surgical intervention given that 2 consecutive series have shown that the dilation tends to become fully stable within 18 months. ${ }^{2,15}$ Thus, we believe that 1.5 years seems be the cutoff time for stabilization of the FDICA.

At our institution, more than 1000 craniopharyngioma resections have been performed, and the interhemispheric subfrontal approach is most commonly used in clinical practice considering the midline origin of the tumor. How- ever, FDICA has not been encountered except in our 2 reported cases. There is no doubt that the surgical approach is closely correlated with the formation of FDICA, and when selecting the lateral approaches such as the pterional approach with or without orbitozygomatic osteotomy, over-traction of the carotid artery should be avoided. As others have mentioned, several surgery-related factors, such as minimized bipolar utilization and piecemeal tumor resection, may lower the incidence of FDICA after radical excision of a craniopharyngioma. ${ }^{5}$

\section{Acknowledgments}

We received financial support from the Beijing Municipal Natural Science Foundation (Grant No. 7161005 to X.S.) and the Science and Technology Commission Foundation of Beijing (Grant No. Z161100000516019 to X.S.).

\section{References}

1. Bendszus M, Sörensen N, Hofmann E, Röll E, Solymosi L: Fusiform dilatations of the internal carotid artery following surgery for pediatric suprasellar tumors. Pediatr Neurosurg 29:304-308, 1998

2. Elliott RE, Wisoff JH: Fusiform dilation of the carotid artery following radical resection of pediatric craniopharyngiomas: natural history and management. Neurosurg Focus 28(4):E14, 2010

3. Hoffmann A, Warmuth-Metz M, Lohle K, Reichel J, Daubenbuchel AM, Sterkenburg AS, et al: Fusiform dilatation of the internal carotid artery in childhood-onset craniopharyngioma: multicenter study on incidence and long-term outcome. Pituitary 19:422-428, 2016

4. Lakhanpal SK, Glasier CM, James CA, Angtuaco EJC: MR and CT diagnosis of carotid pseudoaneurysm in children following surgical resection of craniopharyngioma. Pediatr Radiol 25:249-251, 1995

5. Li Q, Wang C, Xu J, You C: Endovascular treatment for fusiform dilation of internal carotid artery following craniopharyngioma resection: a case illustration. J Child Neurol 30:1354-1356, 2015

6. Linfante I, Tucci C, Andreone V: Fusiform dilatation of the internal carotid artery after craniopharyngioma resection. Pediatr Neurol 39:139-140, 2008

7. Liu SS, Zabramski JM, Spetzler RF, Sutton L, Gusnard D, Bruce D, et al: Fusiform aneurysm after surgery for craniopharyngioma. J Neurosurg 75:670-672, 1991 (Letter)

8. Nagata T, Goto T, Ichinose T, Mitsuhashi Y, Tsuyuguchi N, Ohata K: Pathological findings of fusiform dilation of the internal carotid artery following radical dissection of a craniopharyngioma. J Neurosurg Pediatr 6:567-571, 2010

9. O'Connor MM, Mayberg MR: Effects of radiation on cerebral vasculature: a review. Neurosurgery 46:138-151, 2000

10. Ogilvy CS, Tawk RG, Mokin M, Yang X, Levy EI, Hopkins LN, et al: Stent-assisted coiling treatment of pediatric traumatic pseudoaneurysm resulting from tumor surgery. Pediatr Neurosurg 47:442-448, 2011

11. Shi X, Qian H, Fang T, Zhang Y, Sun Y, Liu F: Management of complex intracranial aneurysms with bypass surgery: a technique application and experience in 93 patients. Neurosurg Rev 38:109-120, 2015

12. Shi X, Qian H, K C KI, Zhang Y, Zhou Z, Sun Y: Bypass of the maxillary to proximal middle cerebral artery or proximal posterior cerebral artery with radial artery graft. Acta Neurochir (Wien) 153:1649-1655, 2011

13. Shi XE, Wu B, Fan T, Zhou ZQ, Zhang YL: Craniopharyngioma: surgical experience of 309 cases in China. Clin Neurol Neurosurg 110:151-159, 2008 
14. Sutton LN: Vascular complications of surgery for craniopharyngioma and hypothalamic glioma. Pediatr Neurosurg 21 (Suppl 1):124-128, 1994

15. Sutton LN, Gusnard D, Bruce DA, Fried A, Packer RJ, Zimmerman RA: Fusiform dilatations of the carotid artery following radical surgery of childhood craniopharyngiomas. J Neurosurg 74:695-700, 1991

16. Tirakotai W, Sure U, Benes L, Aboul-Enein H, Schulte DM, Riegel T, et al: Successful management of a symptomatic fusiform dilatation of the internal carotid artery following surgery of childhood craniopharyngioma. Childs Nerv Syst 18:717-721, 2002

\section{Disclosures}

The authors report no conflict of interest concerning the materi- als or methods used in this study or the findings specified in this paper.

\section{Author Contributions}

Conception and design: Wang. Acquisition of data: Wang, Liu. Analysis and interpretation of data: Wang. Drafting the article: Wang. Critically revising the article: Wang. Reviewed submitted version of manuscript: Wang, Qian. Administrative/technical/ material support: Shi. Study supervision: Shi.

\section{Correspondence}

Xiang'en Shi, Department of Neurosurgery, Sanbo Brain Hospital, Capital Medical University, No. 50, Yikesong Rd., Haidian District, Beijing 100093, People's Republic of China. email: shixen@sina.com. 